Revista Eletrônica de Direito Processual - REDP.

Rio de Janeiro. Ano 11. Volume 18. Número 2. Maio a Agosto de 2017

Periódico Quadrimestral da Pós-Graduação Stricto Sensu em Direito Processual da UERJ

Patrono: José Carlos Barbosa Moreira. ISSN 1982-7636. pp. 136-164

www.redp.uerj.br

\title{
MINISTÉRIO PÚBLICO E GARANTIAS FUNDAMENTAIS: UMA ANÁLISE DO DISCURSO NAS SESSÕES DO TRIBUNAL DO JÚRI NA COMARCA DE RECIFE, PE ${ }^{1}$
}

\section{DISTRICT ATTORNEY AND FUNDAMENTALS RIGTHS: A STUDY ABOUT DISCOURSES OF ACCUSERS IN JURY PLENARY IN RECIFE, PE}

Érica Babini Lapa do Amaral Machado Doutor em Direito pela UFPE. Recife, PE - Universidade Católica de Pernambuco.

http://lattes.cnpq.br/7784333143703014 orcid.org/0000-0001-6930-6284. ericababini@hotmail.com

Raysa Bascopé Pereira da Costa Graduada em Direito pela UNICAP. Recife, PE Universidade Católica de Pernambuco. raysa_bascope@hotmail.com

RESUMO: O trabalho analisa o discurso dos promotores de justiça nas sessões do Tribunal do Júri da Comarca do Recife, afim de verificar se garantias processuais penais são respeitadas na atividade acusatória. Foi realizada revisão bibliográfica acerca do Ministério Público e garantias processuais e, através de abordagem etnográfica e de análise de conteúdo, verificou-se a prática dos membros do Parquet. Concluiu-se que as sustentações orais dos representantes ministeriais não observam as garantias constitucionais dos acusados, já que foram encontrados elementos do direito penal do inimigo, prevalecendo a sanha acusatória e o paradigma de segurança pública.

PALAVRAS-CHAVE: Ministério Público; Tribunal do Júri; garantias fundamentais

\footnotetext{
${ }^{1}$ Artigo recebido em 15/06/2017 e aprovado em 27/06/2017.
} 
Revista Eletrônica de Direito Processual - REDP.

Rio de Janeiro. Ano 11. Volume 18. Número 2. Maio a Agosto de 2017

Periódico Quadrimestral da Pós-Graduação Stricto Sensu em Direito Processual da UERJ

Patrono: José Carlos Barbosa Moreira. ISSN 1982-7636. pp. 136-164

www.redp.uerj.br

ABSTRACT: The authors study prosecutors discourse in the Jury court in Recife city. The objective was to evaluate the respect for fundamental rights in the plenary session. Methodologically bibliographic review was done of the constitutional functions of the District Attorney and content analysis of the material collected by the ethnography research of the sessions. The researchers concluded that the oral arguments of the prosecution are used to manage security despite the constitutional fundamental rights, using elements of the criminal law.

KEYWORDS: District Attorney; Jury Court; fundamental rights

\section{Introdução}

A Constituição Federal de 1988 considerou o Ministério Público como órgão institucional do Estado, autônomo e independente, não integrado ou vinculado a nenhum dos três poderes do sistema de freios e $\operatorname{contrapesos}^{2}$ e foi considerado como "instituição permanente, essencial à função jurisdicional do Estado incumbindo-lhe a defesa da ordem jurídica, do regime democrático e dos interesses sociais e individuais indisponíveis" ${ }^{3}$.

Sobeja clareza que o diploma constitucional outorgou autonomia políticoadministrativa ao órgão ministerial para que possa deliberar sobre assuntos de sua competência. Ou melhor, a instituição não se submete a qualquer outro poder do Estado, "sendo independente para atuar na formação do seu convencimento, com liberdade e livre de interferências externas"4.

A partir dessa atribuição, pode-se destacar que, do ponto de vista processual, o Parquet tem duas funções: a de ser parte na relação jurídica-processual (atua como órgão acusador) e a de ser fiscal da lei (custos legis), devendo o seu representante ministerial agir com imparcialidade, isto é, com uma certa objetividade, livre de idiossincrasias e paixões ${ }^{5}$

\footnotetext{
2 PAES, José Eduardo Sabo. O Ministério Público na construção do Estado Democrático de Direito. Brasília. Editora: Brasília Jurídica, 2003.

${ }^{3}$ BRASIL. Constituição de 1988. Constituição da República. In: Vade Mecum Compacto de Direito Rideel: Obra Coletiva de Autoria da Editora Rideel - 11.ed.- São Paulo: Rideel, 2016.

${ }^{4}$ DEMERCIAN, Pedro Henrique. Regime Jurídico do Ministério Público no Processo Penal. São Paulo: Editora Verbatim, 2009.

${ }^{5}$ DEMERCIAN. Op. Cit.
} 
Revista Eletrônica de Direito Processual - REDP.

Rio de Janeiro. Ano 11. Volume 18. Número 2. Maio a Agosto de 2017

Periódico Quadrimestral da Pós-Graduação Stricto Sensu em Direito Processual da UERJ

Patrono: José Carlos Barbosa Moreira. ISSN 1982-7636. pp. 136-164

www.redp.uerj.br

Dentre os casos de figurar como acusador, deve atuar nos casos de crimes dolosos contra a vida, (art. 121 do CP: homicídio e feminicídio; art. 122 do CP: induzimento, instigação ou auxílio ao suicídio; art. 123 do CP: infanticídio; art. 124: aborto) ${ }^{6}$ que são de competência do Tribunal do Júri.

Assim, em virtude dessa dupla tarefa, o órgão deve pugnar por uma sentença justa, condenação ou absolvição, sempre abstendo-se às provas que foram colhidas na instrução, bem como deve realizar o seu papel de custos legis, observando todas as garantias constitucionais do acusado, além de seguir o procedimento legal.

Segundo Kédyma Cristiane Almeida Silva, pode-se atribuir dupla função ao referido Tribunal: política e jurídica. Há um duplo interesse em jogo: de um lado, os interesses da sociedade, representada pelo Conselho de Sentença, e, de outro, os interesses do acusado que, tem direito a um julgamento justo previsto constitucionalmente ${ }^{7}$.

Pode-se dizer, outrossim, que esta instituição é um freio político para a arbitrariedade dos detentores do poder coator estatal. No Tribunal, a opinião dos jurados é vinculante, isto é, os jurados podem decidir segundo a sua convicção, mesmo que esta não tenha embasamento algum ${ }^{8}$. Nesta esteira, uma das principais funções da participação popular seria "a necessidade de assegurar a integração do tribunal com quem pertence ao mesmo entorno cultural daqueles que devem ser julgados" 9 .

Por outro lado, a Lei Maior garantiu a presunção da inocência até que haja o trânsito em julgado de uma sentença condenatória, sendo esta garantia um direito fundamental. Assim, antes e durante o processo judicial, o agente será presumido inocente, até que se prove o contrário, através do devido processo legal. E, ainda, pode-se dizer que

\footnotetext{
${ }^{6}$ BRASIL. Código Penal. In: Vade Mecum Compacto de Direito Rideel: Obra Coletiva qde Autoria da Editora Rideel - 11.ed.- São Paulo: Rideel, 2016.

${ }^{7}$ SILVA, Kédyma Cristiane Almeida. Reforma da instituição do júri a partir de uma visão garantista dos direitos. Revista Fundação Escola Superior do Ministério Público do Distrito Federal e Territórios. Brasília, Ano 10, Volume 20, p. 76-112, jul./dez. 2002.

${ }^{8}$ ALVAREZ, Marcos Echeveste. Echeveste, Emiliano Saúl. Fernandez, Agustina Aquino. Democratizacíon de La justicia penal: juício por jurados. Universidad Nacional de La Pampa. Faculdade de ciências econômicas y jurídicas. Seminário sobre apostaciones teóricas e técnicas recientes, 2011.

9 VASCONCELOS, Vinicius Gomes de. GALÍCIA, Caíque Ribeiro. Tribunal do júri na justiça criminal brasileira: críticas e propostas de reforma para a restituição de sua função de garantia no processo penal democrática. Revista Eletrônica de Direito Processual - REDP. Volume XIII. Disponível em:

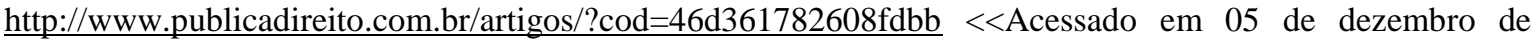
2016>>
} 
Revista Eletrônica de Direito Processual - REDP.

Rio de Janeiro. Ano 11. Volume 18. Número 2. Maio a Agosto de 2017

Periódico Quadrimestral da Pós-Graduação Stricto Sensu em Direito Processual da UERJ

Patrono: José Carlos Barbosa Moreira. ISSN 1982-7636. pp. 136-164

www.redp.uerj.br

esta garantia é direcionada ao Estado ${ }^{10}$, uma vez que este tem a função de processar e julgar o fato que foi imputado ao indivíduo.

O princípio da presunção de inocência, é definido no $5^{\circ}$, LVII da Constituição Federal de 1988, dispõe que "ninguém será considerado culpado até o trânsito em julgado da sentença penal condenatória"11. Assim, pode-se entender que toda e qualquer pessoa será considerada inocente mesmo na fase do inquérito policial (fase pré-processual), até que a sua culpabilidade seja, de fato, $\operatorname{provada}^{12}$.

Antônio Magalhães Gomes Filho citado por Antunes definiu com exatidão o princípio ora elencado $^{13}$ :

Traduz uma norma de comportamento diante do acusado, segundo o qual são legítimos quaisquer efeitos negativos que possam decorrer exclusivamente da imputação, antes da sentença final, toda antecipação de medida punitiva, do que importe reconhecimento da culpabilidade viola esse princípio fundamental.

Desta maneira, é perceptível que o princípio fundamental é direcionado para o Estado $^{14}$, mais precisamente, para o Estado Democrático de Direito, uma vez que este é detentor do poder de polícia. Assim, esta diretriz garante ao sujeito, que se encontra no limbo da persecução criminal, a ideia inicial de não haver cometido ato ilícito algum.

Considerando esses conteúdos o presente trabalho buscará observar a atuação do Ministério Público no Tribunal do Júri na Comarca de Recife, visando compreender, por meio da análise das sustentações orais dos membros da instituição, se as garantias constitucionais e processuais penais são observadas pelos representantes do Parquet.

\section{Processo Penal brasileiro e garantias fundamentais: uma revisão bibliográfica de funções declaradas.}

\footnotetext{
${ }^{10}$ ANTUNES, Flávio Augusto. Presunção de inocência e direito penal do inimigo. 2010110 f. Dissertação. (Mestrado em Direito) - Pontifícia Universidade Católica de São Paulo, São Paulo, 2010.

${ }^{11}$ BRASIL. Constituição de 1988. Constituição da República. In: Vade Mecum Compacto de Direito Rideel: Obra Coletiva de Autoria da Editora Rideel - 11.ed.- São Paulo: Rideel, 2016.

${ }^{12}$ ANTUNES, Flávio Augusto. Op. Cit.

${ }^{13}$ ANTUNES, Flávio Augusto. Op. Cit.

${ }^{14}$ ANTUNES, Flávio Augusto. Op. Cit.
} 
Revista Eletrônica de Direito Processual - REDP.

Rio de Janeiro. Ano 11. Volume 18. Número 2. Maio a Agosto de 2017

Periódico Quadrimestral da Pós-Graduação Stricto Sensu em Direito Processual da UERJ

Patrono: José Carlos Barbosa Moreira. ISSN 1982-7636. pp. 136-164

www.redp.uerj.br

O termo processo vem do verbo procedere que significa avançar, caminhar em direção a um fim e por isso envolve a ideia de temporalidade. É exatamente a situação que a acusação invoca por meio da acusação (ação penal) que o juiz exerça a jurisdição e, ao final, se comprovada a tese acusatória, exerça o poder de punir do Estado.

Neste sentido, importa ponderar uma reflexão - qual o fundamento do processo penal? Ou nas palavras de Aury Lopes Jr. ${ }^{15}$ - Processo Penal para quem? Sim, porque se o ius puniedi corresponde ao Estado que tem poder soberano sobre sues súditos - que acusa e julga, por meio distintos órgãos - por que necessita que prove seu direito em um processo?

A questão é relevante na medida em que o Código de Processo Penal é fruto dessa corrente ideológica anti-liberal. Anamaria Compôs Torres ${ }^{16}$ ressalta que aos magistrados mais vale sacrificar a presunção de inocência à procura da verdade - isso contrasta com a defesa social, que é o verdadeiro norte dessa corrente política. Postura, aliás "tupiniquim", haja vista que o fim do processo é a aplicação da justiça e esta, jamais, poderá ser entendida como sacrifício de direitos do homem em nome de uma pseudo-defesa do organismo social.

O Código de Processo Penal herdou o cunho político-ideológico fascista onde propõe medidas em que se visualize o tratamento de presunção de culpa do investigado/acusado e, na ponderação entre a tutela da segurança jurídica e a tutela da liberdade individual, prevalecendo a preocupação quase sempre da primeira, sempre legitimada pela "busca da verdade real". Grandes exemplos do caráter inquisitivo do Código de Processo Penal é o inquérito policial, silencioso, sem contraditório, onde o juiz deve abster-se de participar desta fase.

Entretanto, a concepção moderna e crítica do processo penal ${ }^{17}$, responderá aquela pergunta que a utilidade do processo é para efetivação das garantias constitucionais, especialmente a partir do constitucionalismo decorrente do Estado Democrático de Direito

15 LOPES JR, Aury. Direito Processual Penal e Sua Conformidade Constitucional. 11 ed. São Paulo: Saraiva, 2014.

16 TORRES, Anamaria Campos. Prova no Processo Penal. Justiça como fundamento Axiológico. Belo Horizonte: Del Rey, 1992.

17 Jacinto Nelson de Miranda Coutinho, Eugenio Pacceli de Oliveira, Aury Lopes Junior, Paulo Rangel, Geraldo Prado, Alexandre de Morais da Rosa e mesmo constitucionalistas como Lenio Streck, vem de forma reiterada asseverando que muitas mudanças são uma aproximação com o princípio acusatório esculpido na Constituição da República. 
Revista Eletrônica de Direito Processual - REDP.

Rio de Janeiro. Ano 11. Volume 18. Número 2. Maio a Agosto de 2017

Periódico Quadrimestral da Pós-Graduação Stricto Sensu em Direito Processual da UERJ

Patrono: José Carlos Barbosa Moreira. ISSN 1982-7636. pp. 136-164

www.redp.uerj.br

é absolutamente necessário que as regras do jogo sejam observadas a partir da Constituição.

Juarez Tavares ${ }^{18}$, de maneira lúcida, aponta algo que parece simples, porém não é. Afirma ele que no modelo constitucional e democrático optado pela sociedade brasileira com a Constituição de 1988, a garantia e o exercício da liberdade individual não precisam qualquer legitimação, em face de sua evidência, o que já não é o mesmo com o poder punitivo do Estado que precisa se justificar.

Isto é, no modelo do Estado Democrático de Direito, é absolutamente necessário que as regras do jogo sejam observadas a partir da Constituição ${ }^{19}$, devendo-se empreender luta para superar a crença de que o processo penal está à serviço da segurança pública. Nas lições de Geraldo Prado, o processo penal é instrumental e está à serviço de uma única finalidade: realização de um projeto democrático, e não à serviço de uma pretensão acusatória, o que significa uma máxima eficiência dos direitos e garantias fundamentais ${ }^{20}$. Neste sentido, o modelo acusatório que impera na estrutura constitucional, tem que a gestão da prova é o critério que demarca a diferença para o processo inquisitivo.

No inquisitório, o juiz carrega poderes de iniciativa e produção probatória, enquanto que no acusatório esse poder é das partes. No modelo inquisitivo, o juiz deixa de ser expectar para ser protagonista e o processo é sigiloso, cabendo a ele buscar a verdade dos fatos, razão pela qual o resultado é colonizado pela resposta satisfatória, afinal, ele tem que justificar sua atuação.

O manual dos inquisidores do catalão Nicolau Eymerich relata o modelo inquisitório do direito canônico que influenciou definitivamente o processo penal. Aliás, o processo inquisitório foi construído a partir de um conjunto de instrumentos e conceitos, especialmente de verdade absoluta, onde a prisão era regra porque o inquisidor tinha à sua disposição o acusado para torturá-lo para buscar a verdade real, e que se bem realizada a confissão, o inquisidor conseguia a confissão que como rainha das provas (sistema de

\footnotetext{
18 TAVARES, Juarez. Teoria do Injusto Penal. 3 ed. Belo horizonte: Del Rey, 2003.

19 LOPES JR, Aury. Direito Processual Penal e Sua Conformidade Constitucional. 11 ed. São Paulo: Saraiva, 2014.

${ }^{20}$ PRADO, Geraldo. A transição democrática no Brasil e o Sistema de Justiça Criminal. Palestra proferida no Ciclo de Conferências organizado pela Faculdade de Direito, pelo Programa de Pós Doutoramento em Democracia e Direitos Humanos e pelo Centro de Estudos Interdisciplinares do Século ${ }^{20}$ da Universidade de Coimbra em 06 de novembro de 2012, no âmbito do módulo de Direito Penal coordenado pela prof ${ }^{\mathrm{a}}$. Cláudia Santos.
} 
Revista Eletrônica de Direito Processual - REDP.

Rio de Janeiro. Ano 11. Volume 18. Número 2. Maio a Agosto de 2017

Periódico Quadrimestral da Pós-Graduação Stricto Sensu em Direito Processual da UERJ

Patrono: José Carlos Barbosa Moreira. ISSN 1982-7636. pp. 136-164

www.redp.uerj.br

provas tarifadas) era suficiente para a punição. Neste sentido, inútil qualquer defesa ${ }^{21}$.

Deve-se pontuar que a passagem do sistema inquisitivo para o acusatório é antes de tudo a transição política do modelo autoritário para o democrático, de modo que democracia e sistema acusatório compartilham da mesma base epistemológica.

E não é possível conceber que o processo brasileiro tenha uma conotação mista inquisitivo na fase policial e acusatório na fase judicial, pois, como relata Jacinto Coutinho, o sistema bifásico do código napoleônico, no qual inspirou-se o Brasil, é monstro de duas cabeças, acabando por valer mais a prova secreta que a do contraditório, numa verdadeira fraude ${ }^{22}$.

No contexto democrático do processo, as garantias processuais são indispensáveis, porque são elas as ferramentas de defesa do cidadão. Em verdade, os princípios têm função interpretativa que servem de vetor orientador ao operador jurídico na interpretação das normas para adequá-las aos valores fundamentais. Nesse sentido, Daniel Sarmento:

Os princípios constitucionais desempenham também um papel hermenêutico constitucional, configurando-se como genuínos vetores exegéticos para a compreensão e aplicação das demais normas constitucionais e infraconstitucionais. Nesse sentido, os princípios constitucionais representam o fio-condutor da hermenêutica jurídica, dirigindo o trabalho do intérprete em consonância com os valores e interesses por eles abrigados. ${ }^{23}$

Diante da compreensão teórica, uma questão se avoluma: na prática é assim que se faz?

\section{A observação etnográfica e a análise de conteúdo do discurso dos membros ministeriais no tribunal do júri}

Antes de iniciar a análise do discurso dos membros do Ministério Público, é preciso tecer breves comentários a respeito da metodologia utilizada para realizar o objetivo do

\footnotetext{
${ }^{21}$ COUTINHO, Jacinto Nelson de Miranda. Introdução aos princípios do Direito Processual Penal brasileiro. In: Separata ITEC, ano $1, \mathrm{n}^{\mathrm{o}} 4-\mathrm{jan} / \mathrm{fev} / \mathrm{mar} 2000$, p. 3.

${ }^{22}$ Apud. LOPES JR, Aury. Direito Processual Penal e Sua Conformidade Constitucional. 11 ed. São Paulo: Saraiva, 2014.

${ }^{23}$ SARMENTO, Daniel. A ponderação de interesses na Constituição Federal. Rio de Janeiro: Lumen Júris, 2000, p. 54.
} 
Revista Eletrônica de Direito Processual - REDP.

Rio de Janeiro. Ano 11. Volume 18. Número 2. Maio a Agosto de 2017

Periódico Quadrimestral da Pós-Graduação Stricto Sensu em Direito Processual da UERJ

Patrono: José Carlos Barbosa Moreira. ISSN 1982-7636. pp. 136-164

www.redp.uerj.br

presente trabalho, uma vez que "o método é a alma da teoria"24. Pode-se dizer, por conseguinte, que tal metodologia é uma maneira, ou melhor, um meio de construção de conhecimento sobre uma realidade social já socialmente construída e historicamente mais ou menos determinada ${ }^{25}$.

No fundo, a metodologia inclui a teoria, ou seja, o método, as técnicas e a criatividade do pesquisador (envolve a experiência, capacidade pessoal e a sensibilidade do pesquisador) ${ }^{26}$. Desta forma, pode-se concluir que para fazer uma abordagem teórica é necessária a utilização da metodologia.

A pesquisa é de cunho qualitativo porque é a mais adequada para "as ciências sociais, uma vez que ela trabalha com o universo dos significados, dos motivos, das aspirações, das crenças, dos valores e das atitudes, as quais, não podem ou não deveriam ser quantificadas" 27 . Desta maneira, por se tratar da análise de conteúdo do discurso dos Promotores de Justiça, a pesquisa não apenas analisará o discurso oral, mas também o seu modo de agir e de pensar.

No fundo, trata-se de uma pesquisa sociojurídica, visto que como bem teceu Luciano Oliveira "[...] é um "modelo" fronteiriço entre a pesquisa jurídica stricto sensu e a pesquisa sociológica lato senso [...] que vai além da pesquisa estritamente jurídica - aquela que se vale dos métodos da dogmática jurídica"28. Desta forma, a pesquisa vai além de uma pesquisa que se restrinja à área jurídica propriamente dita, ou seja, adentra no campo da sociologia, observando comportamentos e discursos que afetam muitas vidas.

Para isso, deve-se partir da compreensão dos instrumentos metodológicos escolhidos, quais sejam, etnografia e análise de conteúdo. Ademais, não se pode deixar de levar em conta que o trabalho poderá passar por algumas dificuldades para a aplicação das

\footnotetext{
${ }^{24}$ MINAYO, Maria Cecília de Souza (organizadora); GOMES, Suely Ferreira Deslandes Romeu. Pesquisa social: teoria, método e criatividade. Petrópolis, Rio de Janeiro. Editora Vozes, 2008, p. 15

${ }^{25}$ ESTEVES, António Joaquim. Metodologias Qualitativas: Análise Etnográfica e Histórias de Vida. In A. Esteves \& J. Azevedo (Eds.), Metodologias qualitativas para as ciências sociais. Porto: Faculdade de Letras da Universidade do Porto. 1998. Disponível em: http://ler.letras.up.pt/uploads/ficheiros/4257.pdf. <<Acesso em 06 de fevereiro de 2017>>.

${ }^{26}$ MINAYO, Maria Cecília de Souza (organizadora); GOMES, Suely Ferreira Deslandes Romeu. Op. Cit.

${ }^{27}$ MINAYO, Maria Cecília de Souza (organizadora); GOMES, Suely Ferreira Deslandes Romeu. Op. Cit.

28 OLIVEIRA, Luciano. Manual de Sociologia Jurídica. Petrópolis, Rio de Janeiro. Editora Vozes, 2015, p. 169
} 
Revista Eletrônica de Direito Processual - REDP.

Rio de Janeiro. Ano 11. Volume 18. Número 2. Maio a Agosto de 2017

Periódico Quadrimestral da Pós-Graduação Stricto Sensu em Direito Processual da UERJ

Patrono: José Carlos Barbosa Moreira. ISSN 1982-7636. pp. 136-164

www.redp.uerj.br

metodologias aplicadas, em virtude de se tratar da exposição oral dos membros Ministério Público ${ }^{29}$.

A etnografia é uma metodologia de pesquisa que permite captar aspectos do objeto de estudo que passariam despercebidos, caso fossem observados exclusivamente por visões macro e de grandes números ${ }^{30}$. Não se trata de um olhar obsecado por detalhes, mas um olhar mais atencioso, que pode dar origem a um novo entendimento, a uma nova teoria ${ }^{31}$.

Por se tratar de uma metodologia mais detalhada e executada com maior atenção, na grande maioria das vezes, é utilizada nas pesquisas de ciências sociais. Outrossim, é inevitável destacar a importância da pesquisa etnográfica para poder fundamentar as teorias que podem vir a ser elaboradas, já que os dois extremos (pesquisa etnográfica e a teoria) deveriam se complementar. Caso contrário, o material etnográfico estaria distante da realidade ${ }^{32}$, se tornando apenas um mero levantamento de dados ${ }^{33}$.

Por outro lado, a análise de conteúdo, segundo Bauer é:

apenas um método de análise de texto desenvolvido dentro das ciências sociais empíricas. Embora a maior parte das análises clássicas de conteúdo culminem em descrições numéricas de algumas características do corpus do texto, considerável atenção está sendo dada aos "tipos", "qualidades", e "distinções" no texto, antes de qualquer quantificação seja feita. Deste modo, a análise de texto faz uma ponte entre o formalismo estatístico e a análise qualitativa dos materiais ${ }^{34}$.

Assim, a análise de conteúdo foi eleita por ser uma metodologia que se adéqua à diversos tipos de objetos de pesquisa, que pode ser facilmente flexibilizada, como no caso do presente trabalho, que tentará analisar o conteúdo do discurso dos representantes

\footnotetext{
${ }^{29}$ SANTOS, Roberta Vanessa da Cruz. A análise de conteúdo dos discursos dos promotores de justiça e a (in)existência do uso do direito penal do inimigo: um estudo sobre o ministério público de Pernambuco nas sessões do tribunal do júri. Monografia. Universidade Católica de Pernambuco, Recife, 2014.

${ }^{30}$ MAGNANI, João Guilherme Cantor. De perto e de Dentro: Notas para uma etnografia urbana. Revista Brasileira de Ciências Sociais. 2002, vol. 17, n49, p. 16. Disponível em: http://www.scielo.br/scielo.php?pid=S0102-69092002000200002\&script=sci_arttext. 《<Acesso em $10 \mathrm{de}$ Março de 2017>>

${ }^{31}$ MAGNANI, João Guilherme Cantor. Op. Cit.

${ }^{32}$ PEIRANO, Mariza. A Favor da Etnografia. Rio de Janeiro. Editora: Relume-Dumará, 1995.

${ }^{33}$ SANTOS, Roberta Vanessa da Cruz. A análise de conteúdo dos discursos dos promotores de justiça e a (in)existência do uso do direito penal do inimigo: um estudo sobre o ministério público de Pernambuco nas sessões do tribunal do júri. Monografia. Universidade Católica de Pernambuco, Recife, 2014.

${ }^{34}$ BAUER, Martin. Análise de Conteúdo Clássica. In: BAUER, Martin; Q., GASKELL, George (editores). Pesquisa qualitativa com texto, imagem e som: um manual prático. Tradução: Pedrinho A. Guareschi. Rio de Janeiro: Editora Vozes. 2002, p.190.
} 
Revista Eletrônica de Direito Processual - REDP.

Rio de Janeiro. Ano 11. Volume 18. Número 2. Maio a Agosto de 2017

Periódico Quadrimestral da Pós-Graduação Stricto Sensu em Direito Processual da UERJ

Patrono: José Carlos Barbosa Moreira. ISSN 1982-7636. pp. 136-164

www.redp.uerj.br

ministeriais nas sessões do Tribunal do Júri através de gravações. É preciso salientar que as gravações, apesar de não haverem sido previamente autorizadas, não foram de encontro com nenhuma norma legal, pois as audiências são públicas e realizadas a portas abertas, nos termos da legislação processual penal.

Para poder analisar o discurso dos promotores, é necessário estabelecer alguns parâmetros que aqui serão chamados de categorias. Bauer ensina que as categorias são modos sistemáticos de comparação ${ }^{35}$. Assim, as categorias que foram utilizadas para analisar servem para fazer uma comparação entre elementos teóricos e o discurso oral dos representantes ministeriais.

A pesquisa foi realizada no ano de 2017, nos meses de janeiro a março, na cidade do Recife, PE, em especial nas sessões da $1^{\circ}$ Vara do Tribunal do Júri (situada no Fórum Desembargador Rodolfo Aureliano), $2^{\circ}$ Vara do Tribunal do Júri (situada no Fórum Desembargador Rodolfo Aureliano) e na $4^{\circ}$ Vara do Tribunal do Júri (situada no Fórum Thomaz de Aquino Cyrillo Wanderley).

Importante destacar que o objetivo do trabalho não é analisar na íntegra as sessões no plenário do tribunal do júri, mas apenas os discursos proferidos pelos promotores de justiça. Assim, todas as cinco sessões foram gravadas e, sucessivamente, exploradas desde o momento da sua abertura até a conclusão da sustentação oral do membro do Ministério Público, durando em média de 2 horas a 3 horas.

Por fim, é necessário informar que a presente pesquisa, é uma espécie de observação-participante, ou seja, as pesquisadoras não deixaram de estar envolvida diretamente no processo de produção de conhecimento, o que leva a ter sentimentos, percepções e, portanto, foi necessário que em alguns momentos a escrita se desse em primeira pessoa, a fim de garantir a transmissão mais fidedigna possível do cenário estudado, afinal a neutralidade absoluta não existe ${ }^{36}$.

\section{Categorias de análise: da presunção de inocência ao Direito Penal do inimigo}

\footnotetext{
35 BAUER, Martin. Análise de Conteúdo Clássica. In: BAUER, Martin; Q., GASKELL, George (editores). Pesquisa qualitativa com texto, imagem e som: um manual prático. Tradução: Pedrinho A. Guareschi. Rio de Janeiro: Editora Vozes. 2002, p.190.

${ }^{36}$ OLIVEIRA, Luciano. Neutros \& Neutros. Humanidades, n. 19, p. 122-127, Brasília, 1988.
} 
Revista Eletrônica de Direito Processual - REDP.

Rio de Janeiro. Ano 11. Volume 18. Número 2. Maio a Agosto de 2017

Periódico Quadrimestral da Pós-Graduação Stricto Sensu em Direito Processual da UERJ

Patrono: José Carlos Barbosa Moreira. ISSN 1982-7636. pp. 136-164

www.redp.uerj.br

Os padrões que foram identificados nos discursos dos promotores, nas cinco sessões do Tribunal do Júri, foram os seguintes:

\subsection{Princípio da presunção de inocência ou de culpabilidade?}

A denominação do princípio da presunção de inocência é bastante discutida se presunção de estado de inocência ou de não culpabilidade, o fato é que este declara que ninguém poderá ser considerado culpado antes do trânsito em julgado da sentença condenatória.

$\mathrm{Na}$ verdade, a confusão terminológica não é meramente gramatical. A CF agasalhou um termo diverso das Declarações e Convenções que já o havia previsto, e com isso levou ao raciocínio de que em face contra quem é instaurada a ação penal, como existe suporte probatório mínimo, haveria impedimento de presumir a inocência, podendo, no máximo presumir a culpabilidade. Assim, poder-se-ia ter que a CF consagrou o princípio da não-culpabilidade, e não o da inocência.

Essas garantias têm bases diferentes. Em termos técnicos, há filiados ao entendimento já dito, mas em termos de concepções político-ideológicas as posturas se bifurcam em dois sentidos, a depender da compreensão da finalidade do processo.

Aqueles que atribuem a essa finalidade a comprovação da pretensão punitiva do Estado, todavia têm o princípio como não-culpabilidade. Todavia, aqueles que advogam a que a finalidade do processo é a proteção do homem face à pretensão punitiva, acolhe-se a presunção de inocência.

O fundamento deste princípio é na proibição do excesso, de forma que as prisões cautelares significam afronta ao princípio que sede vez à segurança coletiva. Só que com as cautelares, tudo fica na esfera da incerteza da inocência, até a sentença final.

A presunção de inocência remonta o direito romano, tendo atacada e invertida na inquisição da idade média, quando a dúvida, gerada pela insuficiência de prova equivalia a uma semi-prova, que comportava um juízo de semi-culpabilidade. Vivia-se a presunção de culpabilidade. Mas o princípio da presunção de inocência e o da jurisdicionalidade foram consagrados na Declaração dos Direitos do Homem de 1789, tendo sido, porém, atacada pelo totalitarismo, a ponto de Manzini chamá-la de “estranho e absurdo extraído do 
Revista Eletrônica de Direito Processual - REDP.

Rio de Janeiro. Ano 11. Volume 18. Número 2. Maio a Agosto de 2017

Periódico Quadrimestral da Pós-Graduação Stricto Sensu em Direito Processual da UERJ

Patrono: José Carlos Barbosa Moreira. ISSN 1982-7636. pp. 136-164

www.redp.uerj.br

empirismo francês”. Neste sentido, o Código de Rocco de 1930 não consagrou o princípio, pois era visto como excesso de individualismo e garantismo.

A Constituição porém, consagrou em seu bojo, cuja relevância não precisaria está positivada em local algum, por ser pressuposto da condição humana. O princípio da presunção da inocência, indica Ferrajoli, é decorrente do princípio da jurisdição, posto que essa é atividade necessária para a obtenção da prova de que alguém cometeu um delito, até que essa prova não se produza, mediante um proceso regular, nenhum delito pode considerar-se cometido e ninguém pode ser considerado culpado, nem submetido a uma pena.

Aliás, dissera ele, é um princípio da civilidade, fruto de uma opção garantista a favor da tutela da imunidade dos inocentes, ainda que se chegue a ser o preço da impunidade do culpável. Isso porque ao corpo social lhe basta que os culpados sejam igualmente punidos, pois o maior interesse é que todos os inocentes, sem exceção, estejam protegidos.

Outrossim, se é verdade que os cidadãos estão ameaçados pelos delitos, também o estão pelas penas arbitrárias, fazendo com que a presunção de inocência não seja apenas uma garantia de liberdade e de verdade, senão também uma garantia de segurança ou defesa social, enquanto segurança oferecida pelo Estado de Direito e que se expressa na confiança dos cidadãos na justiça., pois o medo que a justiça inspira nos cidadãos é signo inconfundível de perda de legitimidade política da jurisdição e ao mesmo tempo de sua involução autoritária e irracional.

É por isso que afirma Ferrajoli: “cada vez que um imputado tem razão em temer um juiz estar-se-á, fora da lógica do estado de direito; o medo e também a desconfiança na segurança do inocente indicam a quebra da função mesma da jurisdição penal e da ruptura dos valores políticos que a legitimam.

Apesar do princípio de presunção de inocência estar elencado como um direito fundamental, na prática não é suficiente para salvaguardar quem está sentado no banco dos réus e seja possuidor de ficha de antecedentes criminais, já que é previamente considerado culpado pelo crime que está ainda em fase de julgamento. 
Revista Eletrônica de Direito Processual - REDP.

Rio de Janeiro. Ano 11. Volume 18. Número 2. Maio a Agosto de 2017

Periódico Quadrimestral da Pós-Graduação Stricto Sensu em Direito Processual da UERJ

Patrono: José Carlos Barbosa Moreira. ISSN 1982-7636. pp. 136-164

www.redp.uerj.br

Os promotores de Justiça, na maioria das vezes, estão tão habituados a observar o passado criminoso do acusado e presumir que "se ele infringiu a lei uma vez, pode fazê-lo novamente".

Apesar dos membros não terem o poder decisório no Tribunal do Júri, existe a indução dos jurados, os quais posteriormente às alegações dos representantes ministeriais darão o seu veredito, conforme a tese condenatória do Ministério Público. Pode-se dizer, inclusive, que o membro ministerial seduz os jurados, conduzindo-os, assim, a uma determinada posição, utilizando-se de argumentos lógicos, artifícios retóricos e visuais a fim de comovê-los ${ }^{37}$.

A seguir, serão demonstrados alguns fragmentos das sustentações dos membros do Ministério Público, obtidos durante a segunda fase do Tribunal Júri, que darão embasamento ao que já foi previamente delineado acima. Nesta ideia, o membro ministerial:

Wil está respondendo por outros crimes, inclusive em um foi condenado a 6 anos de reclusão, e aqui ele quis contar outra história dizendo que não tinha sido condenado...o que eles tinham que fazer agora? Assumir o crime, mas não o fizeram. Será que nesse processo de assalto, o Wilton assumiu? Será que nesse processo de tentativa ele assumiu $?^{38}$.

Neste excerto resta nítida a demonstração dos antecedentes criminais e a figura que os promotores desenham do acusado para os jurados. Em outra sessão, o mesmo padrão é notado quando o promotor menciona a ficha criminal do acusado: "O réu, inclusive, está também respondendo a outros processos, inclusive de homicídio, na quarta vara" ${ }^{39}$. Também, na última sessão, a mesma prática é novamente observada: “inclusive, esse homicídio foi cometido com arma branca, com uma faca, ou seja, já era uma coisa típica dele, matar com faca, para furar pessoas... a vítima foi espancada por ele [aponta para o acusado] e inclusive responde a outros processos, fora esses ${ }^{40}$,

Outrossim, como já foi mencionado, uma prática muito comum que foi observada durante o período da pesquisa, é que os membros se utilizam de outros processos já transitados em julgado em que os indivíduos foram julgados culpados, para demonstrar aos

${ }^{37}$ CHALITA, Gabriel. A sedução no discurso: o poder da linguagem nos tribunais de Júri. São Paulo: Editora Max Limonad, 1998.

${ }^{38}$ Diário de Campo da $1^{\mathrm{a}}$ sessão, realizada em 24/08/2016.

${ }^{39}$ Diário de Campo da $3^{\mathrm{a}}$ sessão, realizada em 10/10/2016

${ }^{40}$ Diário de Campo da $5^{\text {a }}$ sessão, realizada em 02/12/2016 
Revista Eletrônica de Direito Processual - REDP.

Rio de Janeiro. Ano 11. Volume 18. Número 2. Maio a Agosto de 2017

Periódico Quadrimestral da Pós-Graduação Stricto Sensu em Direito Processual da UERJ

Patrono: José Carlos Barbosa Moreira. ISSN 1982-7636. pp. 136-164

www.redp.uerj.br

jurados "a natureza criminosa do suspeito". Nesta esteira, é possível observar que o promotor cria a periculosidade do agente: "O promotor ressalta que o acusado teve sua prisão revogada e foi só a justiça revogar que ele não foi mais achado, tanto é que a sua prisão foi decretada novamente" ${ }^{41}$.

Em muitos casos, quando existem vários acusados (concurso de pessoas), o julgamento de um dos envolvidos é utilizado pelo promotor, no momento de sua sustentação oral, como modelo para influenciar os jurados a tomar a mesma decisão que foi tomada julgamento do outro agente. É possível perceber tal situação no seguinte fragmento: "No julgamento dos outros acusados, os jurados que julgaram entenderam que os acusados foram culpados. A prova foi a mesma, então cabe a vocês decidirem, mas entendam que eles foram considerados culpados, inclusive fui eu que fiz um júri deles." 42

Por conseguinte, restou perceptível a presunção de culpabilidade dos membros do Ministério Público em relação aos acusados, atitude esta que fere um dos direitos fundamentais daquele que está sentado no banco dos réus. Neste âmbito, os antecedentes criminais falam mais alto que o próprio crime que está em julgamento, fazendo que os jurados optem pela culpabilidade do agente. Sendo assim, observa-se que o Parquet se utiliza do processo como um instrumento de acusação, em que a presunção de culpabilidade ofusca a instrução processual, sendo esta, muitas vezes, favorável ao acusado. Os suspeitos, desta maneira, são julgados pelo seu passado criminoso, situação que jamais poderia ser admitida no regime democrático.

\subsection{A superioridade do Ministério Público em relação à defesa}

Muito se fala no princípio da paridade de armas, ou seja, na igualdade das partes no processo, em que a acusação e a defesa são iguais aos olhos do julgador, não havendo uma hierarquia entre a defesa e a acusação, tendo cada polo da ação a sua função no processo ${ }^{43}$.

\footnotetext{
${ }^{41}$ Diário de Campo da $2^{\mathrm{a}}$ sessão, realizada em 05/09/2016.

42 Diário de Campo da $2^{\mathrm{a}}$ sessão, realizada em 05/09/2016.

${ }^{43}$ ROBERTO, Welton. A paridade de armas no processo penal brasileiro: uma concepção do justo processo. 2013. 331 f. Tese (Doutorado em direito) - Universidade Federal de Pernambuco. Recife/Pernambuco. 2013. Disponível http://repositorio.ufpe.br/xmlui/bitstream/handle/123456789/10582/WELTON\%20R.pdf?sequence=1\&isAllo wed $=$ y $<<$ Acessado em 04/03/2017>>
} 
Revista Eletrônica de Direito Processual - REDP.

Rio de Janeiro. Ano 11. Volume 18. Número 2. Maio a Agosto de 2017

Periódico Quadrimestral da Pós-Graduação Stricto Sensu em Direito Processual da UERJ

Patrono: José Carlos Barbosa Moreira. ISSN 1982-7636. pp. 136-164

www.redp.uerj.br

Aliás, Roberto Welton ensinou qual é o verdadeiro papel do processo: "É função precípua da ciência processual procurar equilibrar os instrumentos colocados à disposição da acusação e da defesa, de forma a propiciar que o processo penal, dentro do sistema acusatório, fundado no justo processo, seja dialógico na busca do acertamento da verdade fática penal." 44 Assim, o que se espera é que cada parte (acusação e defesa) cumpra o seu papel $^{45}$, sem ultrapassar os limites estabelecidos pela lei, sem pretender vantagem em relação a outra parte.

Inicialmente, é necessário lembrar a imagem que o Ministério Público tem perante a sociedade, uma vez que lhe foi dada a função de órgão essencial à função jurisdicional do Estado. Entretanto, para a maioria dos cidadãos, ele ainda tem o papel de acusador, de defensor da sociedade, assim, deverá deter todo aquele que ouse perturbar a paz social.

A superioridade da instituição já é algo tão comum na prática que os próprios representantes manifestam esta ideia em seus discursos, como ocorreu neste excerto: "e ai, agora que eu faço as perguntas aos acusados, eles me reperguntam. Não pode isso, existe a ampla defesa, mas não dá o contraditório ao réu. Vamos colocar os pingos nos $i$ 's: acusado é acusado... e o Ministério Público é o Ministério Público ${ }^{46 ”}$. Percebe-se que o promotor, apesar de não deixar explícito, demonstra a superioridade do Ministério Público em relação ao acusado, insinuando que o réu só podia responder o que ela estava perguntando, já que não havia direito ao contraditório.

E ainda, é notável que a maioria dos representantes da instituição pensa ter o direito de desacreditar a defesa de maneira tão explícita, manifestando que: "O Ministério Público não trabalha com teses, com 'achismos', mas sim com o processo, com provas contundentes, o que não é o caso da defesa que, trabalha com teses" ${ }^{\prime 7}$. Na maioria das vezes, então, os promotores, através da sua excelente retórica, fazem com que os jurados acreditem que apenas o Parquet trabalha com provas consistentes e verdadeiras, ao passo que a defesa se utiliza de teses "mirabolantes".

\footnotetext{
${ }^{44}$ ROBERTO, Welton. A paridade de armas no processo penal brasileiro: uma concepção do justo processo. 2013. 331 f. Tese (Doutorado em direito) - Universidade Federal de Pernambuco. Recife/Pernambuco. 2013. Disponível em: http://repositorio.ufpe.br/xmlui/bitstream/handle/123456789/10582/WELTON\%20R.pdf?sequence=1\&isAllo wed $=$ y <<Acessado em 04/03/2017>>

${ }^{45}$ ROBERTO, Welton. Op. Cit.

${ }^{46}$ Diário de Campo da $1^{\mathrm{a}}$ sessão, realizada em 24/08/2016.

${ }^{47}$ Diário de Campo da $1^{\text {a }}$ sessão, realizada em 24/08/2016.
} 
Revista Eletrônica de Direito Processual - REDP.

Rio de Janeiro. Ano 11. Volume 18. Número 2. Maio a Agosto de 2017

Periódico Quadrimestral da Pós-Graduação Stricto Sensu em Direito Processual da UERJ

Patrono: José Carlos Barbosa Moreira. ISSN 1982-7636. pp. 136-164

www.redp.uerj.br

Outro hábito que foi observado no campo de pesquisa foi o da aproximação e companheirismo que os membros ministeriais têm com os jurados, perdendo, assim, a imparcialidade entre promotor-jurado. Na maioria das sessões, os promotores sentavam na plateia e conversavam com os jurados ${ }^{48}$, inclusive, muitas vezes, os promotores recebiam diversos elogios pelo corpo de jurado, expressões como: “o senhor é um excelente promotor", "nunca vi um homem tão íntegro, como o senhor", "o senhor é muito justo e sabe fazer muito bem o seu trabalho", "doutor, gosto muito de trabalhar com o senhor", entre outros inúmeros enaltecimentos.

Desta forma, pode-se dizer que talvez o julgamento dos jurados não é totalmente imparcial, já que estes mantêm uma relação de amizade com os membros do Parquet. Assim, a probabilidade dos seus julgamentos irem de encontro com a tese ministerial é mínima, fugindo, portanto, do objetivo legal da instituição do Tribunal do Júri - o julgamento de cidadãos imparciais. Podendo-se, desta forma, dizer que os jurados seriam uma mera extensão do órgão em questão

A discricionariedade na utilização das provas pelo Parquet é outra característica que pode ser facilmente identificada. Neste sentido, pode-se perceber o desequilíbrio da relação processual entre a instituição ora estudada e o acusado, em que as provas que são demonstradas em plenário variam de acordo com a conveniência da tese do representante do Ministério Público. Desta maneira, quando as provas da fase de instrução judicial são mais adequadas para a sustentação oral, elas prevalecerão e serão tomadas como verdades absolutas e demonstradas em plenário. Por outro lado, se as provas do inquérito policial fossem mais convenientes seriam utilizadas da mesma forma ${ }^{49}$, ou seja, existe uma manipulação das provas pelo representante ministerial apesar da lei $^{50}$ requerer que a instrução na fase judicial seja levada em conta, já que houve a oportunidade do contraditório.

Não se pode deixar de relatar o fato dos membros ministeriais se utilizarem das imagens do laudo tanatoscópico para impressionar os jurados, eles demonstrando "o quão cruel foi o acusado matando a vítima", mostram os ferimentos, os orifícios por onde

\footnotetext{
${ }^{48}$ Diário de Campo da $2^{\mathrm{a}}$ sessão, realizada em 05/09/2016.

${ }^{49}$ Diário de Campo da $2^{\mathrm{a}}$ sessão, realizada em 05/09/2016

${ }^{50}$ BRASIL. Código de Processo Penal. In: Vade Mecum Compacto de Direito Rideel: Obra Coletiva de Autoria da Editora Rideel - 11.ed.- São Paulo: Rideel, 2016.
} 
Revista Eletrônica de Direito Processual - REDP.

Rio de Janeiro. Ano 11. Volume 18. Número 2. Maio a Agosto de 2017

Periódico Quadrimestral da Pós-Graduação Stricto Sensu em Direito Processual da UERJ

Patrono: José Carlos Barbosa Moreira. ISSN 1982-7636. pp. 136-164

www.redp.uerj.br

passaram os projéteis, a quantidade de sangue, o local onde estavam ${ }^{51}$. E muitos dos jurados se impressionam com as fortes imagens e com as palavras do representante da instituição, levando-os a acreditar que, verdadeiramente, o acusado foi cruel com a vítima, não merecendo, portanto, a sua credibilidade. Pode-se constatar, igualmente, a utilização desta injeção de medo pelos promotores de justiça para causar impacto aos jurados, maior comoção na hora do seu julgamento e, consequentemente, obter a tão almejada sentença condenatória para "este indivíduo perigoso".

Desta forma, demonstrou-se a ideia de superioridade do Ministério Público em relação ao acusado, havendo, portanto, uma ofensa ao princípio da paridade de armas, não só pelo prestígio que o órgão ministerial tem, como o "protetor da sociedade", mas também pelo fato dos membros do Parquet, em seus discursos, manifestarem uma posição superior em relação ao querelado, transparecendo, inclusive, essa ideia em plenário.

\subsection{O bem contra o mal: o maniqueísmo em plenário}

A priori, é preciso conceituar a categoria ora analisada. Segundo José Rosa:

[...] o maniqueísmo assenta numa profunda contradição entre o dogma central - o dualismo substancial e metafísico, segundo o qual Bem e Mal, Luz e Trevas, Matéria e Espírito são naturezas eternas, igualmente poderosas, absolutamente diferentes, e, portanto, não se podem misturar nem relacionar (plano de jure) —, e a afirmação de que as mesmas se misturaram efetivamente ${ }^{52}$.

A partir dessa passagem, vê-se que o maniqueísmo é a ideia do bem em confronto com o mal, ou seja, são os dois extremos que não podem se misturar em um mesmo meio. E trazendo esta teoria para o campo de pesquisa, pode-se dizer que o mal estaria representado pelo acusado, o qual atua como inimigo que perturba a paz social, enquanto que o bem seria representado por todas as vítimas ou até a própria sociedade que está sofrendo com as ações do algoz.

\footnotetext{
${ }^{51}$ Diário de Campo da $2^{\text {a }}$ sessão, realizada em 05/09/2016.

52 ROSA, José Maria Silva. Da Cisão Extrema, no Maniqueísmo à Identidade como relação em Confissões $X$. Covilhã: Artigo Lusosofia. 2008, p. 7
} 
Revista Eletrônica de Direito Processual - REDP.

Rio de Janeiro. Ano 11. Volume 18. Número 2. Maio a Agosto de 2017

Periódico Quadrimestral da Pós-Graduação Stricto Sensu em Direito Processual da UERJ

Patrono: José Carlos Barbosa Moreira. ISSN 1982-7636. pp. 136-164

www.redp.uerj.br

O acusado é visto, dessa maneira, como o inimigo pelo poder punitivo, que discrimina e lhe confere um tratamento que não corresponde à condição de agente detentor de garantias do Estado Democrático de Direito, já que este é considerado apenas como um ente perigoso ou daninho para a sociedade ${ }^{53}$. Mesmo que essa "classe" de inimigo social seja inadmissível no Estado constitucional em que se vive, onde só se pode admitir privações de garantias em caso de guerra, e ainda com as limitações impostas pelos tratados de direitos humanos, de âmbito internacional. E, mesmo nos casos de guerra não se permite privar qualquer inimigo da sua condição de pessoa humana ${ }^{54}$.

Nesta esteira, já que o mal [inimigo] está interrompendo a paz da sociedade, o Estado tem o dever de contê-lo, e, após essa contenção, lhe será retirado a sua qualidade de pessoa $^{55}$, em que, segundo Zaffaroni, os indivíduos acabam por serem “coisificados". Em outras palavras, a ideia de priorizar a segurança da coletividade com a suposição da realização de uma conduta que alguém poderia realizar em prejuízo da sociedade, fazendo mais sentido, portanto, que respeitar os direitos daquele que pode um dia estar à margem da $l e i^{56}$.

Assim, já que o acusado é considerado um inimigo no direito, ele será "punido só em razão de sua condição de ente perigoso para a sociedade" ${ }^{57}$, devendo, portanto, ser contido pelo poder de polícia.

Portanto, após uma breve exposição dessa contraposição entre o bem (na figura da vítima ou da sociedade) e o mal (na figura do acusado), é preciso demonstrar fragmentos dos discursos dos membros ministeriais que evidenciem o que foi supramencionado:

A vítima não tem antecedentes, era informante da polícia, dificultando o trabalho dos traficantes... A vítima, depois do atentado, viu um dos acusados no shopping, e teve uma conclusão lógica: se eles atentaram contra a minha vida, dando cinco tiros, obviamente eles querem me pegar agora então decidiu procurar o DHPP...Os acusados estão ai sentado, no banco dos réus, por opção, porque eles infringiram a lei, o artigo 121 do Código Penal. Eles quiseram matar a vítima porque esta era informante

\footnotetext{
${ }^{53}$ ZAFFARONI, Eugenio Raúl. $O$ inimigo no direito penal. Tradução de Sérgio Lamarão. Rio de Janeiro: Revan 2007.

${ }^{54}$ ZAFFARONI, Eugenio Raúl. Op. Cit.

${ }^{55}$ ZAFFARONI, Eugenio Raúl. O inimigo no direito penal. Tradução de Sérgio Lamarão. Rio de Janeiro: Revan 2007.

${ }^{56}$ ZAFFARONI, Eugenio Raúl. Op. Cit.

${ }^{57}$ ZAFFARONI, Eugenio Raúl. p. 25
} 
Revista Eletrônica de Direito Processual - REDP.

Rio de Janeiro. Ano 11. Volume 18. Número 2. Maio a Agosto de 2017

Periódico Quadrimestral da Pós-Graduação Stricto Sensu em Direito Processual da UERJ

Patrono: José Carlos Barbosa Moreira. ISSN 1982-7636. pp. 136-164

www.redp.uerj.br

da polícia [...] Excelências, se eles forem absolvidos hoje, não ficarão soltos porque tem outros processos, mas se eles não tivessem, eles iriam atrás da vítima... é simples assim, é assim que as coisas funcionam ${ }^{58}$.

Em outro julgamento pôde ser observado a mesma linguagem maniqueísta:

Você vê a índole e caráter dos acusados, que atiraram em Dona Domerinda, uma anciã de 85 anos [...] essa velhinha de 85 anos, baixinha, correu para sua porta para tentar fecha-la, já que os acusados tinham arrombado, ai o acusado hoje julgado, mandou atirar nesta pobre anciã que estava em casa apenas com seu marido de $86 \operatorname{anos}^{59}$

Nesse extrato a promotora aduz que a vítima era um cidadão do bem, não tinha uma ficha criminal, um informante da polícia, ao passo que os acusados são tão temidos ao ponto da vítima presumir que ao encontrar algum deles em um shopping center, iriam atentar, novamente, contra sua vida. Outrossim, no segundo fragmento o promotor deixa claro a idade avançada da vítima e sua falta de forças para impedir com que o suspeito agisse, utilizando-se, inclusive, da palavra "índole" para descrever a personalidade do agente. Percebe-se exatamente essa bipolarização entre o bem e o mal, entre o cidadão e o não cidadão (inimigo).

Igualmente, no primeiro julgamento, o promotor ressalta que os acusados estão sentados no banco dos réus por pura opção. Mais uma vez, então, se pode conferir a demonstração pela representante da "natureza criminosa" do acusado, em que é ressaltado que o recém pronunciado cometeu o crime pela sua própria escolha.

No trecho a seguir, pode-se constatar como o membro vitimiza demasiadamente a vítima para ganhar a compaixão dos jurados, ao manifestar que a vítima quase morreu, pois estava exposto a inúmeros perigos no hospital, e ainda finaliza indagando o que ocorreria se essa situação ocorresse com os próprios jurados ou seus entes queridos:

Temos que ver isso, analisar este processo cuidadosamente! Porque não é a gente que ta quase morrendo, que vai pro hospital, que vai levar nosso parente no hospital, porque foi baleado e esta quase morrendo. Não é a gente que vai pegar uma infecção hospitalar e vai morrer [...] Mas senhores jurados, os senhores podem até pensar: mas ele não morreu! É

${ }^{58}$ Diário de Campo da $1^{\text {a }}$ sessão, realizada em 24/08/2016.

${ }^{59}$ Diário de Campo da $2^{\mathrm{a}}$ sessão, realizada em 05/09/2016 
Revista Eletrônica de Direito Processual - REDP.

Rio de Janeiro. Ano 11. Volume 18. Número 2. Maio a Agosto de 2017

Periódico Quadrimestral da Pós-Graduação Stricto Sensu em Direito Processual da UERJ

Patrono: José Carlos Barbosa Moreira. ISSN 1982-7636. pp. 136-164

www.redp.uerj.br

né? Porque não foi o filho da gente né? Não foi um parente da gente que quase morreu! Rir da desgraça alheia é muito bom, mas quando é com a gente né? Ai o bicho pega! ${ }^{60}$

Essa prática é muito comum nos plenário do Tribunal do Júri, pois os promotores, na maioria das vezes, ressaltam a situação da vítima, evidenciando como ela era trabalhadora, tinha uma família e contribuía para o progresso da sociedade. Inclusive, questionam aos jurados: "e se fosse com você?". Essa inversão de papel sugerida pela representante, portanto, retira dos jurados a objetividade que é necessária para o posterior julgamento, levando-os ao plano do subjetivismo, ao campo de emoções, o que, obviamente, não é o pretendido pelo procedimento legal.

Outro hábito dos membros do Parquet em plenário os termos utilizados em plenário ao se referir ao acusado e àqueles que praticam crimes, termos como "bandido" e "marginal" são utilizados a todo tempo durantes as sessões: "Porque o galinheiro pra bandido que mata gente é na cadeia mesmo... Aliás o mais difícil do mundo é um bandido dizer que é culpado"61. E no mesmo julgamento o promotor, em sua sustentação, manifestou: "Ele era bem machinho pra matar a mulher dele, que o tirou de dentro de casa" ${ }^{\prime 62}$.

Importante trazer à tona, que a honra dos acusados está sendo ferida, a qual é garantida constitucionalmente. No entanto, o que se observa, na realidade, é a ideia do direito penal do inimigo, já que o acusado é perigoso para a sociedade e, por isso, perde todas as suas garantias, mesmo aquelas previstas pela Constituição da República. Aliás, Klaus Günther afirma que o cerceamento de direitos da minoria em prol da segurança da maioria anularia o contrato social ${ }^{63}$.

Mesmo se o acusado confessasse o crime, não há mais o que se falar ou investigar, ainda que as testemunhas em seus depoimentos afirmem o contrário. Se o acusado confessasse a sua autoria no crime, o órgão ministerial, na prática, já teria todas as provas necessárias para requerer a sua condenação:

\footnotetext{
${ }^{60}$ Diário de Campo da $1^{\text {a }}$ sessão, realizada em 24/08/2016

${ }^{61}$ Diário de Campo da $2^{\text {a }}$ sessão, realizada em 05/09/2016

${ }^{62}$ Diário de Campo da $4^{\mathrm{a}}$ sessão, realizada em 13/10/2016.

${ }^{63}$ GÜNTHER, Klaus. Os cidadãos mundiais: entre a liberdade e a segurança. Revista Novos Estudos, $\mathrm{n}^{\circ} 83$, 2009. Disponível em: http://www.scielo.br/scielo.php?script=sci_arttext\&pid=S0101-33002009000100002 <<Acessado em: 16 de março de 2017>>
} 
Revista Eletrônica de Direito Processual - REDP.

Rio de Janeiro. Ano 11. Volume 18. Número 2. Maio a Agosto de 2017

Periódico Quadrimestral da Pós-Graduação Stricto Sensu em Direito Processual da UERJ

Patrono: José Carlos Barbosa Moreira. ISSN 1982-7636. pp. 136-164

www.redp.uerj.br

Eu não vou precisar utilizar todo o meu tempo para explicar a culpabilidade deste senhor, pois ele já confessou, então não há muito que se falar [...] Não podemos confiar, integralmente, nos depoimentos das pessoas que foram ouvidas como testemunhas, são do mesmo meio do réu e vítima, que é um meio da criminalidade, do tráfico de drogas, então devemos nos ater ao que o réu nos disse hoje em seu depoimento ${ }^{64}$.

Ora, há muito tempo que não há uma hierarquização entre as provas, e desta forma a confissão deixou de ser a "rainha das provas" como acontecia no sistema da prova tarifada $^{65}$. A Constituição da República de 1988 e o Código de Processo Penal ${ }^{66}$ adotaram o sistema do livre convencimento motivado tendo a confissão o mesmo valor probatório dos demais meios de prova ${ }^{67}$. Neste entendimento, a confissão será utilizada como mais um meio de prova, em que o juiz a confrontará com as demais do conjunto probatório, para compara-las e observar se existe alguma compatibilidade ou concordância ${ }^{68}$. Assim, mesmo nos casos em que o suspeito confessa o crime, o promotor deve analisar o conjunto probatório integralmente, para só a partir desta análise, formar a sua tese e apresentá-las ao corpo de jurados.

No caso sob análise a situação é ainda mais grave, uma vez que as testemunhas relataram que o suspeito não tinha sido o autor do crime, ou seja, o promotor não seguiu a orientação da legislação uma vez que, adotou um sistema de provas que não vigora no Estado Democrático de Direito. E ainda pode-se dizer que o representante cria estereótipos das testemunhas questionando a sua credibilidade pelo simples fato de residirem em zonas periféricas, onde predomina o tráfico de entorpecentes. Será que se estas afirmassem a culpabilidade do suspeito, ainda se traria à tona o fato destas viverem em zonas com altos índices de criminalidade?

Após essa breve análise pode-se chegar a uma conclusão: o Ministério Público está retomando as suas raízes de órgão acusador, originárias do estado altamente absolutista, e está deixando de lado a função designada pelo Estado Democrático de Direito, a de fiscal da lei. Aliás, Zaffaroni foi claro ao discorrer: "O direito penal cultivou as sementes do

\footnotetext{
${ }^{64}$ Diário de Campo da $3^{\mathrm{a}}$ sessão, realizada em 10/10/2016.

${ }^{65}$ LIMA, Renato Brasileiro. Manual de Processo Penal. Salvador-Bahia: Editora JusPodivm, 2014

${ }^{66}$ BRASIL. Código de Processo Penal. Op. Cit.

${ }^{67}$ LIMA, Renato Brasileiro. Op. Cit.

${ }^{68}$ LIMA, Renato Brasileiro. Op. Cit.
} 
Revista Eletrônica de Direito Processual - REDP.

Rio de Janeiro. Ano 11. Volume 18. Número 2. Maio a Agosto de 2017

Periódico Quadrimestral da Pós-Graduação Stricto Sensu em Direito Processual da UERJ

Patrono: José Carlos Barbosa Moreira. ISSN 1982-7636. pp. 136-164

www.redp.uerj.br

Estado absoluto. Quase sempre os que quiseram conter o poder punitivo parcialmente também o habilitaram como direito penal do inimigo" 69

\subsection{O Poder Judiciário como "salvador"}

O objetivo deste tópico será demonstrar, nas sustentações dos representantes ministeriais, a deturpação do real papel do poder judiciário nos discursos ministeriais, no sentido de tal sistema ser empregado como um instrumento de resposta à sociedade. A partir da pesquisa, pode-se dizer que para os promotores de Justiça, na maioria das vezes, o julgamento é a oportunidade que a instituição tem para demonstrar à sociedade e, principalmente, à vítima que se está fazendo justiça, assegurando, desta maneira, a manutenção da paz, como pode ser observado neste trecho a seguir: "Por fim, eu quero dizer a vossas excelências que confio muito em vocês e tenho certeza que mais uma vez faremos justiça".

Por se tratar dos crimes contra a vida, de grande repercussão no meio social, a tendência dos membros é comunicar à sociedade e à vítima e/ou aos seus parentes que o culpado está sendo punido pelas suas atitudes.

Pode-se dizer, ademais, que as autoridades estatais, através do seu poder, exibem o suposto cumprimento da lei e fazem lembrar que aquele que não a respeitar terá o mesmo destino do acusado. Em outras palavras, com essa conduta os promotores visam convencer os jurados utilizando-se da cultura do medo para garantir, teoricamente, a maior segurança.

Este fragmento demonstra como o poder judiciário é utilizado para dar a ideia de proteção contra aquele que perturba a paz e tranquilidade social: "Minha gente, não é só o São Paulo e o Rio de Janeiro que está dominado pelo tráfico e por histórias como essas, e eles tão crescendo sabe por quê? Porque não tem uma resposta imediata do Estado, que responsabilize logo" 70 .

No trecho acima pode-se evidenciar que o promotor mencionou as cidades que têm um alto nível de tráfico de entorpecentes e as equipara com a cidade do Recife, relatando que os índices de ocorrência do tráfico está aumentando, e o motivo disso é o Estado não

${ }^{69}$ ZAFFARONI, Eugenio Raúl. $O$ inimigo no direito penal. Tradução de Sérgio Lamarão. Rio de Janeiro: Revan 2007, p. 191.

${ }^{70}$ Diário de Campo da $1^{\text {a }}$ sessão, realizada em 24/08/2016 
Revista Eletrônica de Direito Processual - REDP.

Rio de Janeiro. Ano 11. Volume 18. Número 2. Maio a Agosto de 2017

Periódico Quadrimestral da Pós-Graduação Stricto Sensu em Direito Processual da UERJ

Patrono: José Carlos Barbosa Moreira. ISSN 1982-7636. pp. 136-164

www.redp.uerj.br

estar dando uma punição imediata. Assim, caso a punição fosse efetuada com maior rapidez, o nível de criminalidade não cresceria. Pode-se ver que a visão da representante é extremamente punitivista, em que a única saída para extinguir a criminalidade é o isolamento social.

Como já foi brevemente discorrido, a cultura do medo nos discursos dos promotores é uma característica muito presente, a qual se utiliza de frases que identificam o acusado como um ser altamente perigoso, que precisa ser contido para que não continue causando danos. Isso se pode explicar pelo simples fato da complexidade da sociedade, haja vista a ideia de que o Estado tem o dever de proteger os seus cidadãos de qualquer ameaça. No entanto, por diversas vezes, em razão de inúmeros problemas de gestão, não consegue exercer essa "tarefa/dever", facilitando, desta forma, a instalação do medo no inconsciente das pessoas ${ }^{71}$.

Essa manifestação do pânico e alerta para a sociedade, por conseguinte, acaba por descrever os acusados como verdadeiros desordeiros e de alto potencial ofensivo. para demonstrar isso a promotora de utiliza do seguinte discurso: "Pra vocês verem que os traficantes estão tão importantes que eles até decidem quem vai viver e quem vai morrer"72.

\section{CONSIDERAÇÕES FINAIS}

O principal objetivo deste trabalho foi realizar observação etnográfica, além de analisar o conteúdo do discurso dos membros do Ministério Público, na dinâmica das sessões do tribunal popular da Comarca de Recife para compreender em que medida garantias processuais seriam observadas.

O processo penal tem um papel nitidamente garantista no modelo democrático, ou seja, a matéria processual oferece ao acusado mecanismos de proteção contra qualquer ato absolutista advindo do Estado. Desta maneira, "ninguém será considerado culpado até o

\footnotetext{
${ }^{71}$ SILVEIRA, Felipe Lazzari da. A cultura do medo e sua contribuição para a proliferação da criminalidade. Anais: Congresso Internacional de Direito e Contemporaneidade, 2013, UFSM - Universidade Federal de Santa Maria, Santa Maria- RS. Disponível em: http://coral.ufsm.br/congressodireito/anais/2013/3-1.pdf <<Acessado em 08 de março de 2017>>.

${ }^{72}$ Diário de Campo da $1^{a}$ sessão, realizada em 24/08/2016
} 
Revista Eletrônica de Direito Processual - REDP.

Rio de Janeiro. Ano 11. Volume 18. Número 2. Maio a Agosto de 2017

Periódico Quadrimestral da Pós-Graduação Stricto Sensu em Direito Processual da UERJ

Patrono: José Carlos Barbosa Moreira. ISSN 1982-7636. pp. 136-164

www.redp.uerj.br

trânsito em julgado de sentença penal condenatória",73, a não ser que a sua culpa seja verdadeiramente comprovada. É perceptível, portanto, que o Estado Democrático não dá lugar a um julgamento pautado na personalidade do acusado, em que se presume a culpabilidade através da sua ficha criminal, mas sim na comprovação do delito através de provas concretas, onde a presunção de inocência é a regra.

De igual forma, foi observada a função do Ministério Público na esfera criminal, devidamente prescrita pelo diploma processual penal, como parte-autora da relação jurídico-processual e como fiscal da lei (custos legis) ${ }^{74}$. Assim, apesar da instituição ser amplamente conhecida como "órgão acusador", após a instalação do Estado Democrático, a dupla função do órgão tornou-se imprescindível em todos os âmbitos de sua atuação, principalmente, na esfera criminal, nas ações penais públicas como é o caso do Tribunal do Júri.

Neste entendimento, foi verificado que o Parquet deverá observar as diretrizes legais, mesmo sendo interessado na ação. Destarte, à luz da Lei Maior e do regime democrático, não é função do Ministério Público sustentar a qualquer custo a acusação do sujeito, não havendo um dever de acusação, mas um dever de submissão às garantias e princípios democráticos, já que não há essa adversidade entre acusação e defesa. Ainda é necessário salientar que, apesar desta posição de "superioridade" dada pela legislação, no âmbito da ação penal pública, a instituição não detém nenhuma prerrogativa em relação ao acusado.

A pesquisa de campo realizada no Tribunal do Júri, indicou uma nítida presunção de culpabilidade, indo, desta forma, pela contramão das garantias do Estado Democrático de Direito. A inclinação dos promotores de justiça pela condenação e pelo encarceramento está entre as primeiras opções, apesar de ocorrerem casos em que o representante ministerial pugnou pela absolvição do acusado, como ocorreu em um dos cinco casos demonstrados neste trabalho.

\footnotetext{
${ }^{73}$ BRASIL. Constituição de 1988. Constituição da República. In: Vade Mecum Compacto de Direito Rideel: Obra Coletiva de Autoria da Editora Rideel - 11.ed.- São Paulo: Rideel, 2016.

${ }^{74}$ BRASIL. Código de Processo Penal. In: Vade Mecum Compacto de Direito Rideel: Obra Coletiva de Autoria da Editora Rideel - 11.ed.- São Paulo: Rideel, 2016.
} 
Revista Eletrônica de Direito Processual - REDP.

Rio de Janeiro. Ano 11. Volume 18. Número 2. Maio a Agosto de 2017

Periódico Quadrimestral da Pós-Graduação Stricto Sensu em Direito Processual da UERJ

Patrono: José Carlos Barbosa Moreira. ISSN 1982-7636. pp. 136-164

www.redp.uerj.br

Adentrando no objetivo principal da pesquisa, foram observados alguns padrões nas sustentações orais dos membros nas sessões do Tribunal do júri, os quais foram representados como categorias no trabalho em tela.

Nesse sentido, nos discursos dos representantes, a ficha criminal do acusado é levada em conta, na maioria esmagadora das vezes, de modo que a presunção de inocência termina por ser substituída pela ideia de: "se ele infringiu a lei uma vez pode fazê-lo novamente", atitude segundo o qual foi demonstrada com fragmentos dos discursos dos membros em plenário. Esta prática dos membros transparece nas sessões e termina por induzir aos jurados à condenação daquele que se encontra no limbo da ação criminal, não pelo fato que lhe foi incriminado, mas pelos seus antecedentes criminais.

Outrossim, tratou-se da superioridade que o órgão ministerial tem em relação ao acusado, não só pelo fato dos representantes terem em mente que a sua instituição está em um patamar superior, mas também pelo fato de, em alguns casos, desacreditarem a sustentação oral dos defensores, ao ponto de interromper o seu discurso por diversas vezes, sem que essas intervenções fossem necessárias.

Nesta categoria ainda foram observadas traços de "coleguismo" entre o membro ministerial e o corpo de jurados, fato que pode afetar a imparcialidade do conselho de sentença no momento do seu julgamento, além de haver se constado a discricionariedade na utilização das provas, já que, a depender da tese, se utilizavam da instrução ou das provas do inquérito policial.

$\mathrm{Na}$ pesquisa de campo também foi observada a ideia do maniqueísmo nas sustentações dos membros ministeriais, na qual o bem (representado pela vítima do crime ou mesmo pela sociedade) estaria em confronto com o mal (estaria na figura do suspeito). Assim, observou-se que os acusados são descritos como inimigos, ou até criaturas perigosas que precisam ser contidas para deixar de transtornar a sociedade, utilizando-se, mais uma vez, um discurso baseado na cultura do medo para disseminar tal ideologia em plenário.

Conjuntamente, foi observado como os membros do Parquet acreditam que o sistema judiciário é um meio utilizado para dar resposta e para tranquilizar a sociedade após a ocorrência de um crime, afinal, a sociedade precisa que o Estado aponte o autor da desestabilização da paz social. 
Revista Eletrônica de Direito Processual - REDP.

Rio de Janeiro. Ano 11. Volume 18. Número 2. Maio a Agosto de 2017

Periódico Quadrimestral da Pós-Graduação Stricto Sensu em Direito Processual da UERJ

Patrono: José Carlos Barbosa Moreira. ISSN 1982-7636. pp. 136-164

www.redp.uerj.br

Desta maneira real atuação do Parquet implica a redução a um órgão acusador, distanciando-se do ofício de fiscal da lei. Consequentemente, emprega-se uma lógica bélica, já que, em plenário, o extermínio do indivíduo criminoso do meio social é um objetivo a ser alcançado, utilizando-se, para isso, elementos da teoria do inimigo do direito penal; características latentes de um estado absolutista, desprovido de garantias constitucionais, portanto.

Também se observou que a praxe da instituição era requerer a condenação/pena, sendo esta avistada como solução para todos os casos, utilizando-se, portanto, o direito penal como prima ratio, fato inconcebível no modelo de um regime democrático.

Desta forma, a atuação dos promotores de justiça não condiz com o modelo de Estado Democrático de Direito, já que existem abusos às garantias constitucionais, pela adoção de uma postura notoriamente acusatória por parte de um órgão denominado, por excelência, como fiscal da lei.

\section{REFERÊNCIAS BIBLIOGRÁFICAS:}

ANTUNES, Flávio Augusto. Presunção de inocência e direito penal do inimigo. 2010110 f. Dissertação. (Mestrado em Direito) - Pontifícia Universidade Católica de São Paulo, São Paulo, 2010.

BAUER, Martin. Análise de Conteúdo Clássica. In: BAUER, Martin; Q., GASKELL, George (editores). Pesquisa qualitativa com texto, imagem e som: um manual prático.Tradução: Pedrinho A. Guareschi. Rio de Janeiro: Editora Vozes. 2002.

BRASIL. Código Penal. In: Vade Mecum Compacto de Direito Rideel: Obra Coletiva qde Autoria da Editora Rideel - 11.ed.- São Paulo: Rideel, 2016.

BRASIL. Código de Processo Penal. In: Vade Mecum Compacto de Direito Rideel: Obra Coletiva de Autoria da Editora Rideel - 11.ed.- São Paulo: Rideel, 2016.

BRASIL. Constituição de 1988. Constituição da República. In: Vade Mecum Compacto de Direito Rideel: Obra Coletiva de Autoria da Editora Rideel - 11.ed.- São Paulo: Rideel, 2016.

CHALITA, Gabriel. A sedução no discurso: o poder da linguagem nos tribunais de Júri. São Paulo: Editora Max Limonad, 1998. 
Revista Eletrônica de Direito Processual - REDP.

Rio de Janeiro. Ano 11. Volume 18. Número 2. Maio a Agosto de 2017

Periódico Quadrimestral da Pós-Graduação Stricto Sensu em Direito Processual da UERJ

Patrono: José Carlos Barbosa Moreira. ISSN 1982-7636. pp. 136-164

www.redp.uerj.br

COUTINHO, Jacinto Nelson de Miranda. Introdução aos princípios do Direito Processual

Penal brasileiro. In: Separata ITEC, ano 1, nº 4 - jan/fev/mar 2000.

DEMERCIAN, Pedro Henrique. Regime Jurídico do Ministério Público no Processo Penal. São Paulo: Editora Verbatim, 2009.

ESTEVES, António Joaquim. Metodologias Qualitativas: Análise Etnográfica e Histórias de Vida. In A. Esteves \& J. Azevedo (Eds.), Metodologias qualitativas para as ciências sociais. Porto: Faculdade de Letras da Universidade do Porto. 1998. Disponível em: http://ler.letras.up.pt/uploads/ficheiros/4257.pdf. 〈<Acesso em 06/02/2017〉〉.

GLASSNER, Barry. Cultura do Medo [Tradução Laura Knappl]. São Paulo: Editora Francis, 2003.

LEITE, Bruna Eitelwein. A influência da mídia no princípio da presunção de inocência no tribunal do júri. Monografia. Pontifícia Universidade Católica do Rio Grande do Sul, Rio Grande do Sul, 2011. Disponível em: http://www3.pucrs.br/pucrs/files/uni/poa/direito/graduacao/tcc/tcc2/trabalhos2011_1/bruna _leite.pdf <<Acessado em 04 de dezembro de 2016〉>

LIMA, Renato Brasileiro. Manual de Processo Penal. Salvador-Bahia: Editora JusPodivm, 2014.

LOPES JR, Aury. Direito Processual Penal e Sua Conformidade Constitucional. 11 ed. São Paulo: Saraiva, 2014.

MAGNANI, João Guilherme Cantor. De perto e de Dentro: Notas para uma etnografia urbana. Revista Brasileira de Ciências Sociais. 2002, vol. 17, n 49, p. 16. Disponível em: http://www.scielo.br/scielo.php?pid=S0102-69092002000200002\&script=sci_arttext.

$<<$ Acesso em 10/03/2014>>

MINAYO, Maria Cecília de Souza (organizadora); GOMES, Suely Ferreira Deslandes Romeu. Pesquisa social: teoria, método e criatividade. Petrópolis, Rio de Janeiro. Editora Vozes, 2008.

OLIVEIRA, Luciano. Manual de Sociologia Jurídica. Petrópolis, Rio de Janeiro. Editora Vozes, 2015.

. Sua Excelência o Comissário e outros ensaios de Sociologia Jurídica. Rio de Janeiro: Letra Legal, 2004.

Neutros \& Neutros. Humanidades, n. 19, p. 122-127, Brasília, 1988. 
Revista Eletrônica de Direito Processual - REDP.

Rio de Janeiro. Ano 11. Volume 18. Número 2. Maio a Agosto de 2017

Periódico Quadrimestral da Pós-Graduação Stricto Sensu em Direito Processual da UERJ

Patrono: José Carlos Barbosa Moreira. ISSN 1982-7636. pp. 136-164

www.redp.uerj.br

PAES, José Eduardo Sabo. O Ministério Público na construção do Estado Democrático de

Direito. Brasília. Editora: Brasília Jurídica, 2003.

PEIRANO, Mariza. A Favor da Etnografia. Rio de Janeiro. Editora: Relume-Dumará, 1995.

PRADO, Geraldo. A transição democrática no Brasil e o Sistema de Justiça Criminal. Palestra proferida no Ciclo de Conferências organizado pela Faculdade de Direito, pelo Programa de Pós Doutoramento em Democracia e Direitos Humanos e pelo Centro de Estudos Interdisciplinares do Século 20 da Universidade de Coimbra em 06 de novembro de 2012, no âmbito do módulo de Direito Penal coordenado pela prof. Cláudia Santos.

ROBERTO, Welton. A paridade de armas no processo penal brasileiro: uma concepção do justo processo. 2013. 331 f. Tese (Doutorado em direito) - Universidade Federal de Pernambuco. Recife/Pernambuco. 2013. Disponível em: http://repositorio.ufpe.br/xmlui/bitstream/handle/123456789/10582/WELTON\%20R.pdf?s equence $=1 \&$ isAllowed=y $\langle<$ Acessado em 04/03/2017>>

ROSA, José Maria Silva. Da Cisão Extrema, no Maniqueísmo à Identidade como relação em Confissões X. Covilhã: Artigo Lusosofia. 2008

SANTOS, Roberta Vanessa da Cruz. A análise de conteúdo dos discursos dos promotores de justiça e a (in)existência do uso do direito penal do inimigo: um estudo sobre o ministério público de Pernambuco nas sessões do tribunal do júri. Monografia. Universidade Católica de Pernambuco, Recife, 2014.

SARMENTO, Daniel. A ponderação de interesses na Constituição Federal. Rio de Janeiro: Lumen Júris, 2000.

SILVA, Kédyma Cristiane Almeida. Reforma da instituição do júri a partir de uma visão garantista dos direitos. Revista Fundação Escola Superior do Ministério Público do Distrito Federal e Territórios. Brasília, Ano 10, Volume 20, p. 76-112, jul./dez. 2002.

SILVEIRA, Felipe Lazzari da. A cultura do medo e sua contribuição para a proliferação da criminalidade. Anais: Congresso Internacional de Direito e Contemporaneidade, 2013, UFSM - Universidade Federal de Santa Maria, Santa Maria- RS. Disponível em: http://coral.ufsm.br/congressodireito/anais/2013/3-1.pdf <<Acessado em 08 de março de 2017>>.

TAVARES, Juarez. Teoria do Injusto Penal. 3 ed. Belo horizonte: Del Rey, 2003. 
Revista Eletrônica de Direito Processual - REDP.

Rio de Janeiro. Ano 11. Volume 18. Número 2. Maio a Agosto de 2017

Periódico Quadrimestral da Pós-Graduação Stricto Sensu em Direito Processual da UERJ

Patrono: José Carlos Barbosa Moreira. ISSN 1982-7636. pp. 136-164

www.redp.uerj.br

TORRES, Anamaria Campos. Prova no Processo Penal. Justiça como fundamento Axiológico. Belo Horizonte: Del Rey, 1992.

VASCONCELOS, Vinicius Gomes de. GALÍCIA, Caíque Ribeiro. Tribunal do júri na justiça criminal brasileira: críticas e propostas de reforma para a restituição de sua função de garantia no processo penal democrática. Revista Eletrônica de Direito Processual REDP. Volume XIII. Disponível em: http://www.publicadireito.com.br/artigos/?cod=46d361782608fdbb <<Acessado em 05 de dezembro de 2016>>.

ZAFFARONI, Eugenio Raúl. O inimigo no direito penal. Tradução de Sérgio Lamarão. Rio de Janeiro: Revan 2007. 